\title{
Managerial Turnover With Reference To Mumbai and Thane District
}

\author{
Bharti Valechha \\ (Bbi, Smt.Chm College, India)
}

\begin{abstract}
This Research attempts to seek the causes of Organizational Turnover because the Human resource has tremendous effect on an organization for a business; the greatest asset or expenditure is the human resource of that enterprise. The problem of organizational turnover of manager retention is an expensive one for the business in India, but actually all over the world.though there has been much discussion over the years as to just what the real problem is, what it might be, and what business practitioners and observers think senior managers are always the key performers in an business. What they do, reflect the objective, plans, policies and progress of an organization. Professional managers spend less time trying to manage and more relating to colleagues.
\end{abstract}

\section{Introduction:}

Category of the professional manager is distinct from owners. It is the manager who do the right things and do the things right. A professional manager as defined by Mr. Louis Allen, is the one, who specializes in the work of planning, organizing, leading and controlling the efforts of the other and does it through systematic use of classified knowledge, a common vocabulary and principles; and who subscribes to the standards of practice and code of ethics established by a recognized body.

\section{An attempt was made in the present study to find out:}

$>$ The causes of managerial turnover.

$>$ Whether the growth of I.T Industries has affected total number and status of the middle level managers.

$>$ The analyses the effects of managerial turnover on the organizational strikers.

$>$ The impact of change over on the careers of managers.

$>$ To examine the co-relation between organizational restructuring and managerial turnover.

$>$ To determine the standards for calculating the cost of executive turnover.

\section{By assuming: .}

$>$ The changing times are witnessing reducing importance of middle level managerial personnel.

$>$ The tendency of 'High flying among managers, in general, is on an increase.

$>$ Unlike early Eighties, money is no more the major cause of turnover for managers.

$>$ Companies are yet indifferent towards the managerial turnover problems and costs involved in the same.

$>$ There is attitudinal change towards the negative outlook about executive turnover.

For the purpose of this study, organizations from private sectors were selected from all over Mumbai and Thane with the help of random sampling technique structured questionnaire was prepared to elicit primary data from around 100 managers. Primary data was collected through questionnaire, observation, personal discussion with various levels of managers. For the effective cost analysis, industrial concerns above 500 employee's strengths were included in the sample size.

To study the various effects of high attrition rates, varied industries were studied. Responses of the managers from different sectors of the industries are shown in the following diagram. (Percentage wise)

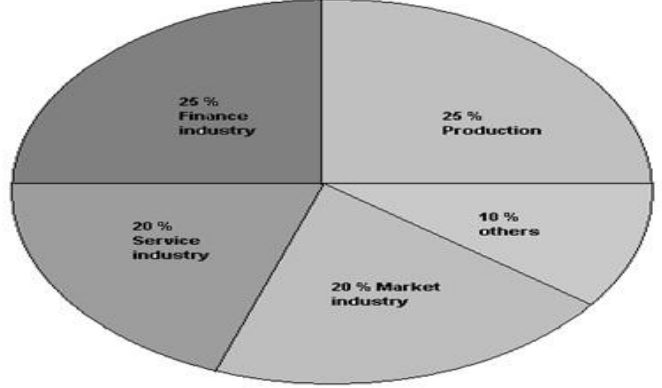




\section{Type of Industries}

While analysing the results for the purpose of findings, the forms were sent across different companies from various industries. Satisfactory and complete responses were collected from 100 respondents as shown in the table below.

Respondents

\begin{tabular}{|l|l|l|}
\hline Sr. No. & Type of Industry & No. of Responses \\
\hline 1. & Finance & 25 \\
\hline 2. & Marketing & 20 \\
\hline 3. & Service & 20 \\
\hline 4. & Production & 25 \\
\hline 5. & Others & 10 \\
\hline & Total & 100 \\
\hline
\end{tabular}

While studying 25 responses were collected from finance industry, 20 responses were collected from marketing industry, 20 responses were collected from service industry, 25 responses were collected from production industry, and 10 responses were collected from other industries.

\section{Study suggests that:}

PERKS, PROMOTION, PROSPECTS, POSITION, and POWER ARE THE 5 P'S the efficient managers are waiting as a millennium's gift. Respect; Recognition, and reward are the basis of their stability.

It is suggested that managerial mobility can be controlled by way of perks, incentives and listening their problems etc.

Company needs the most when things turnaround and competition heats up. Retaining good employees hence keeping the good ones is still essential.

1) Respect all the good ones.

2) Empower the talented executive.

3) Compensate them to their efficiency.

4) Maintain good relationship.

Specialty functions requiring specified attributes however will need careful designing in terms of compensation.

Attractive ways of compensation will include two phases.

1. Basic structures

2. Competitive structures

Basic structures to include:

Dealth programmers: Self and family, Accidental, Life

$>$ Performance Rewards: Stock Options, Bonuses, Individual

$>$ Salary Allowances: basic, fringe, perquisites

Competitive structures shall include:

$>$ Retention of Talent: Appraisal Schemes, Market based benefits

$>$ Attracting of Talent: Long term incentives, High scale rewards

$>$ Saving for Executive: Tax saving plans, Post retirement medical and other benefits

\section{Study concludes that:}

As from the study it is concluded that the ratio of executive turnover is increasing in the economy \& executive turnover is probably the single biggest problem facing most Indian organizations today. The major reason of today is not the money but there are so many other reasons like position \& status, promotional \& growth opportunities, career extensions, growth of IT, job satisfaction etc. Many of the companies are not aware of the mobility of managers \& equilibrium of turnover is achieved when as many good people join \& few go whereas of the bad people many of them go. Due to mobility of managers the organizations hire someone work for them. For that it has to invest time, money, training \& trust that is also loss of organization. I $t$ is concluded that so many personal and general causes are responsible for turnover of the managers. It can be seen from the studythat turnover of the companies has increased from 5\% to $20 \%$ and this turnover of the managers is been accepted by $70 \%$ managers and $30 \%$ managers were not aware of the managerial mobility.

This study shows the professional responses about retaining the present job, their satisfaction with HR their responses were $70 \% \mathrm{v} / \mathrm{s} 30 \%$ "No v/s Yes". It means HR is not co-ordinating or not responding them properly. Even though average amount of money spend on recruitment and training by the companies annually round about 25 to 50 lacs per annum. 
This study concludes lot of reasons for managerial turnover like growth and development, dissatisfaction with previous jobs, personal reasons .and reason for retaining their present job like career advancement, corporate culture, balance between personal and professional life, financial rewards etc.

\section{Journals:}

\section{References:}

[1] N. A. Berg : What is Different about Conglomerate Management (Harvard Business Review Vol. 47, no.6, Nov. Dec. 1969 pp. 112-120)

[2] Norburn D. and Miller : Strategy and Executive reward: Journal of general Management Vol. 6 No. 4 1981 pp17-27

[3] Andrews I.R. and Henry M.M. Management Attitudes Toward Pay, Industrial Relations Vol. No. 3 Oct. 1963, pp29-39.

\section{Books :}

[4] Herzberg F. Mausner B. and Synderman B. The Motivation to Work (New York): Wiley 1959)

[5] Sarma A.M. - Personnel and Human Resource Development, Himalaya Publishing, 2005.

[6] Arnold H.J. and Feldman - Organizational Behavior 1986, Tat McGraw Hills Publication

[7] Banarjee Shyamal Principles and Practices Of Management 1981; Oxford and Ibh Publication.

[8] Barkas J.L. - Creative Time Management 1984 Prentice Hall. 